\title{
Effect of VC, FYM, S, Zn, Azotobacter and PSB on Growth and Yield Attributes of Maize and Wheat
}

\author{
Pushpendra Kumar*, S. D. Dubey, U. S. Tiwari, R. K. Pandey, \\ Karam Hussain and R. K. Singh \\ Department of Soil Science and Agril. Chemistry, C. S. Azad University of Agriculture and \\ Technology, Kanpur-208002, India \\ *Corresponding author
}

A field experiment was conducted at Agriculture Farm of Chandra Shekhar Azad University of Agriculture and Technology, Kanpur to study the effect of Vermicompost, FYM, sulphur, zinc, Azotobacter and PSB on growth, yield and uptake of nutrients in maize and their residual effect on succeeding wheat during

Keywords

Azotobacter, phosphorus solubilising bacteria, organic manure

Article Info

Accepted:

25 May 2021

Available Online:

10 June 2021 2018-19 and 2019-20. The results of the experiment revealed that the growth and yield attributes of maize viz., plant population, plant height, length and diameter of cobs and 1000 grain weight were significantly increased with $\mathrm{T}_{14}(100 \% \mathrm{RDN}+25 \% \mathrm{~N}-$ $\mathrm{VC}+\mathrm{S}+\mathrm{Zn}+\mathrm{Az}+\mathrm{PSB})$ followed by $\mathrm{T}_{13}(100 \% \mathrm{RDN}+25 \% \mathrm{~N}-\mathrm{FYM}+\mathrm{S}+\mathrm{Zn}+\mathrm{Az}+\mathrm{PSB})$, $\mathrm{T}_{10}(100 \% \mathrm{RDN}+\mathrm{S}+\mathrm{Zn}+\mathrm{Az}+\mathrm{PSB})$ during both the years and on pooled mean basis. It was further noticed that the application of $\mathrm{T}_{14}$ in maize significantly improved the growth and yield contributing parameters of wheat viz., plant height, spike length, 1000 grain weight except plant population during both the years of experimentation. The results revealed that the integrated use of either 75 or $100 \%$ RDN with VC or FYM in maize significantly enhanced the growth and yield attributing parameters of maize as well as succeeding wheat. It was also noticed that the application of S and $\mathrm{Zn}$ further improved the growth and yield attributes of maize and wheat. It clearly indicated that the addition of FYM or VC with $\mathrm{S}, \mathrm{Zn}$ and Az+PSB in maize significantly increased the growth and yield attributes of maize and wheat during both the years of experimentation.

\section{Introduction}

Maize (Zea mays) popularly known as corn is one of the most important cereal of the world agriculture as staple food for human being, feed for animals as well as providing valuable industrial raw materials. In the context of world, $58 \%$ of maize is utilized in animal feed, $16 \%$ in human food and $26 \%$ in bioethanol production (HLPE, 2013). It ranks third amongst the food crops, stands after rice and wheat both in terms of area and production. Globally, The United States of America (USA) is the largest producer of maize 
contributes nearly $35 \%$ of the total production in the world and maize is the driver of the US economy. The USA has the highest productivity $\left(>9.6 \mathrm{t} \mathrm{ha}^{-1}\right)$ which is double than the global average $\left(4.92 \mathrm{t} \mathrm{ha}^{-1}\right)$. Whereas, the average productivity of India is $3.02 \mathrm{t} \mathrm{ha}^{-1}$. In India maize is grown in an area of $9.47 \mathrm{~m}$ ha with the production of 28.72 million tonnes while the average productivity is only $3032 \mathrm{~kg}$ $\mathrm{ha}^{-1}$. The predominant maize growing states, contributes more than $80 \%$ of the total maize production are Andhra Pradesh (20.9 \%), Karnataka (15.00 \%), Rajasthan (13.00 \%), Maharashtra (9.1 \%), Bihar (8.9\%), Uttar Pradesh (6.1 \%), Madhya Pradesh (10.00\%), Himachal Pradesh (4.4 \%). However, in Uttar Pradesh it contributes 7.87 and 5.14 per cent in terms of area and production with an average productivity of $1981 \mathrm{~kg} \mathrm{ha}{ }^{-1}$ (Anonymous 2017-18). It is the most versatile crop with wider adaptability in diverse agroecosystems and has highest genetic yield potential among food grain crops, owing to this it is termed as "queen of cereal". It is widely grown in tropical, subtropical and temperate regions of the world throughout the year mainly due to its photo-thermoinsensitive character.

As both the crops require high nutrient and response well to higher levels of inorganic fertilizers and exhibit full yield potential when nutrients supplies in balanced proportion at proper time. No doubt to replenish the soil nutrient depletion, application of chemical fertilizers is essential. The application of chemical fertilizers play significant role by improving the yield as well as balancing the nutrient through replenishment of soil nutrients ultimately improving soil fertility and productivity. Although fertilizers alone are unable to maintain the long-term soil health and crop productivity (Brar et al., 2015) as they lack in secondary and micronutrients. Furthermore, continued indiscriminate and disproportionate use of high analysis inorganic fertilizers devoid of secondary and/or micronutrients coupled with less addition of organic source in the intensive cropping system has led to severe depletion of soil organic matter resulted in the widespread emerging multiple nutrient deficiencies; particularly secondary and micronutrients. It is assuming major challenges for achieving the desirable agricultural intensification required to feed quality food to the burgeoning population. The emerging scenario necessitates the need for the adoption of practices which maintain soil health, makes the production system more sustainable, and provides quality food for meeting the nutritional requirements. Therefore, to maintain soil fertility and to ensure food security in India, the use of other alternative options of soil fertility replenishment is indispensable. Although, various long term research results have shown that neither organic nor mineral fertilizers alone can achieve sustainability in crop production. Rather, integrated use of organic and inorganic fertilizers has become more effective in maintaining higher productivity and stability through correction of deficiencies of primary, secondary and micronutrients.

\section{Materials and Methods}

A field experiment was conducted during kharif and rabi seasons of 2018-19 and 201920 at Student's Instructional Farm, C.S. Azad University of Agriculture and Technology, Kanpur (UP) situated at between $25^{\circ} 26^{\prime}$ to 26 ${ }^{0} 58$ ' North latitude and $79^{0} 31$ ' to $80{ }^{0} 34$ ' East longitude at an elevation of $125.9 \mathrm{~m}$ above mean sea level. The region falls under agroclimatic zone V (Central Plain Zone) of Uttar Pradesh. The soil of the experimental field was alluvial in origin. The experiment was laid out in completely randomized block design with three replications treatments replicated thrice and plot size was $6 \times 5 \mathrm{~cm}^{2}$. Maize Variety Azad Uttam was sown in kharif 
whereas HD-2967 was taken as wheat variety during rabi season. was $\mathrm{g}$ In the present experiment fourteen treatments viz., $\mathrm{T}_{1}$ (control), $\mathrm{T}_{2}(75 \% \mathrm{RDN}), \mathrm{T}_{3}(75 \% \mathrm{RDN}+25$ $\% \mathrm{~N}-\mathrm{FYM}), \mathrm{T}_{4}(75 \% \mathrm{RDN}+25 \% \mathrm{~N}-\mathrm{VC}), \mathrm{T}_{5}$ $(75 \%$ RDN +25 \% $\mathrm{N}-\mathrm{FYM}+\mathrm{S}+\mathrm{Zn}+\mathrm{Az}+$ PSB), $\quad \mathrm{T}_{6} \quad(75 \quad \% \quad \mathrm{RDN}+25 \quad \% \quad \mathrm{~N}-\mathrm{VC}$ $+\mathrm{S}+\mathrm{Zn}+\mathrm{Az}+\mathrm{PSB}), \mathrm{T}_{7}(100 \% \mathrm{RDN}), \mathrm{T}_{8}(100 \%$ $\mathrm{RDN}+\mathrm{S}), \mathrm{T}_{9}(100 \% \mathrm{RDN}+\mathrm{S}+\mathrm{Zn}), \mathrm{T}_{10}(100 \%$ $\mathrm{RDN}+\mathrm{S}+\mathrm{Zn}+\mathrm{Az}+\mathrm{PSB}), \mathrm{T}_{11}(100 \% \mathrm{RDN}+25$ $\% \mathrm{~N}-\mathrm{FYM}), \mathrm{T}_{12}(100 \% \mathrm{RDN}+25 \% \mathrm{~N}-\mathrm{VC})$, $\mathrm{T}_{13} \quad(100 \% \quad \mathrm{RDN}+25 \quad \% \quad \mathrm{~N}-\mathrm{FYM}+\mathrm{S}+\mathrm{Zn}+$ Az+PSB), $\mathrm{T}_{14}(100 \% \mathrm{RDN}+25 \% \mathrm{~N}-\mathrm{FYM}+\mathrm{S}+$ $\mathrm{Zn}+\mathrm{Az}+\mathrm{PSB}$ ) were applied in maize. Whereas in wheat a similar RDF (@ 120:60:40) of NPK was given in all the treatments of maize. The soil of the experimental field was sandy loam in texture which was low in organic carbon (3.35 $\mathrm{g} \mathrm{kg}^{-1}$ ), slightly alkaline in reaction. The soil was low in available $\mathrm{N}$ (156 $\left.\mathrm{kg} \mathrm{ha}^{-1}\right)$, medium in available $\mathrm{P}\left(10.34 \mathrm{~kg} \mathrm{ha}^{-}\right.$ $\left.{ }^{1}\right)$, high in available $\mathrm{K}\left(198.16 \mathrm{~kg} \mathrm{ha}^{-1}\right)$, low in available $\mathrm{S}\left(14.20 \mathrm{~kg} \mathrm{ha}^{-1}\right.$ and medium in available $\mathrm{Zn}\left(0.36 \mathrm{mg} \mathrm{kg}^{-1}\right)$.

\section{Field preparation}

The experimental field was ploughed once with soil turning plough fallowed by two cross harrowing. After each operation, planking was done to level the field and to obtain the fine tilth. Finally layout was done and plots were demarked with small sticks and rope with the help of manual labour in each block. Application of fertilizers:

The crop was fertilized as per treatment. The recommended dose of nutrient i.e. $\mathrm{N}$, $\mathrm{P}$, and $\mathrm{K}$ was applied @ 120: 60: 40 kg ha-1 respectively. Time and method of fertilizer: Half does N2 and total phosphorus, potash, zinc and sulphur were applied as basal dressing. Remaining dose of nitrogen was applied through top dressing after knee-high stage. Well decompose FYM applied @ 60 t ha-1 15 day after sowing. Seed Treatment: To ensure the seeds free from seed borne diseases, seeds were treated with thiram $75 \%$ WDP (1.5g/kg of seed). Seed and sowing: 20 $\mathrm{kg}$ seed ha-1 maize variety Azad Uttam was used and sown on 22 June 2017. Row to row and plant to plant distance remain 60 and 20 respectively. Seed were sown about $5-6 \mathrm{~cm}$. depth. Intercultural operations: Weeding and hoeing were done with khurpi and hand hoe after germination. Irrigation: Tube-well was the source of irrigation. Irrigation was provided in the crop as and when required. Harvesting: The crop was harvested at proper stage of maturity as determined by visual observations.

\section{Biometric observation}

The observations were recorded as per the procedure described below. For this purpose 5 plants were selected randomly in each net plot and were tagged with a level for recording various observations on growth and yield parameters. Biometric observation: Biometric observation such as plant population, plant height at maturity, length and diameter of cobs, test weight of 1000 .

\section{Plant population}

The initial plant population (per square meter) was recorded after thinning and final plant population was counted before harvesting of crop. For counting plant population, one meter scale at three places in each plot was ear marked after thinning. In marked places, plants were counted for both initial and final population. The total of all the plants from three places was divided by three to get number of plants per running meter.

\section{Plant height}

The height of maize plants was measured in $\mathrm{cm}$ at harvesting stage from ground level to transverse mark of top portion of the plant. The average value was used for statistical analysis. 


\section{Plant height}

The height of maize plants was measured in $\mathrm{cm}$ at harvesting stage from ground level to transverse mark of top portion of the plant. The average value was used for statistical analysis.

\section{Length and diameter of cob}

Length and girth of five randomly selected cobs from sampled plants were measured in $\mathrm{cm}$ and the average was worked out. Girth of dehusked cobs was measured separately at three places in each crop, middle and lower portion and then average value was worked out.

\section{Results and Discussion}

\section{Growth and yield attributes of maize}

Growth and yield parameters like plant population, plant height, cob weight, 1000 grain weight, length and diameter of cobs were influenced significantly with different treatments applied in maize during both the years and on pooled mean basis.

\section{Plant population}

The plant count at initial stage and harvest could not differ significantly with the application of different treatments as depicted in table 1.0. The maximum plant stand at initial and harvest stage recorded with treatment of $\mathrm{T}_{14} \quad(100 \% \quad \mathrm{RDN}+25 \% \quad \mathrm{~N}$ $\mathrm{VC}+\mathrm{S}+\mathrm{Zn}+\mathrm{Az}+\mathrm{PSB})$ followed by $\mathrm{T}_{13}((100 \%$ $\mathrm{RDN}+25 \% \quad \mathrm{~N}-\mathrm{FYM}+\mathrm{S}+\mathrm{Zn}+\mathrm{Az}+\mathrm{PSB}) . \quad$ The increase in plant stand might be attributed to fact as organic manure adds sufficient amount of organic matter thereby improved soil physical conditions i.e., soil porosity and water holding capacity (Gaur, 1994, Prasad and Sinha, 2000; Bhattacharyya et al., 2008). At initial stage the plant number could not differ significantly might be due to fact that the seed germination largely depends upon vigour and genetic makeup of the seed. The other factors like moisture, light and air were commonly available to the all seeds applied in the different treatment.

Whereas, at final stand, the plant stand was recorded maximum in $\mathrm{T}_{14}(100 \% \mathrm{RDN}+25 \%$ $\mathrm{N}-\mathrm{VC}+\mathrm{S}+\mathrm{Zn}+\mathrm{Az}+\mathrm{PSB}$ ) whilst lowest in $\mathrm{T}_{1}$ (control). Plant population was gradually decreased from initial to final stage in both the years, due to biotic and abiotic stress during crop growth period. Similar results were also reported by Balasubramaian and Ramamoorthy (1996). Integrative application of inorganic sources with organic manures increased the availability of nutrients, and showed higher plant population compared to application of inorganic fertilizers. A similar result of higher final plant population observed with application of integration of organic manures with fertilizers was reported by Gunri and Nath (2012) and Yogendra Kumar et al., (2013).

\section{Plant height}

The plant height was significantly influenced with the application of any level of nutrients over control $\left(\mathrm{T}_{1}\right)$ during both the years (table 2.0). The application of $\mathrm{N}$ through FYM or VC either with $75 \%$ or $100 \%$ RDN significantly contributed for the enhancement of plant height over their respective RDN. The application of $100 \%$ RDN with $25 \% \mathrm{~N}$ through FYM or VC, Sulfur, Zinc, Azotobacter and PSB attained maximum plant height than any other treatment but among themselves no significant effect was observed however, application of VC was found numerically best for enhancement of plant height of maize. These results are in close conformity with the findings of Kannan et al., (2013) and Naveed et al., (2008) 


\section{Length and diameter of cobs}

Among the various treatments under study the diameter of cobs ranged from 7.71 to $8.65 \mathrm{~cm}$ and 7.69 to $8.70 \mathrm{~cm}$ during first and second year respectively (table 3.0). Whereas, length of cobs varied from12.33 to 14.52 and 12.31 to $14.56 \mathrm{~cm}$ in that order. The result clearly revealed that the treatment $\mathrm{T}_{14}(100 \%$ $\mathrm{RDN}+25 \%-\mathrm{VC}+\mathrm{S}+\mathrm{Zn}+\mathrm{Az}+\mathrm{PSB})$ recorded maximum cob diameter as well as length of cob and significantly superior to which was significantly superior to control, $75 \% \mathrm{RDN}$, $100 \%$ RDN, and VC or FYM with 75 or 100 $\%$ RDN75\% and remained statistically at par value with rest of the treatments. The increase in length and diameter of cobs at higher nutrient levels or addition of organics fertilizer and sulphur and zinc might be due to their positive impact for supply of plant nutrients in adequate and balance quantities to the crop throughout growth and development period resulting to increase in total photosynthetic area, dry matter accumulation and translocation of photosynthates towards sink as reported by Sarwar et al., (2007).

\section{Test weight}

The perusal of data as presented in table reveals the test weight ranged from 221.81 to 224.06 and 221.80 to 224.10 during first and second years, respectively. The data clearly indicates that the maximum test weight was recorded with the application of $\mathrm{T}_{14}(100 \%$ $\mathrm{RDN}+25 \%-\mathrm{VC}+\mathrm{S}+\mathrm{Zn}+\mathrm{Az}+\mathrm{PSB})$ which was highly significant than $\mathrm{T}_{1}$ (control), $\mathrm{T}_{2}$ (75\% RDN), $\mathrm{T}_{3}(75 \% \mathrm{RDN}+25 \% \mathrm{~N}-\mathrm{FYM})$ and $\mathrm{T}_{4}$ $(75 \% \quad \mathrm{RDN}+25 \% \quad \mathrm{~N}-\mathrm{VC})$ and remained statistically at par with the rest of the treatments. The increase of test weight might be due to the application of inorganic fertilizers along with organic manure could have encouraged the better rhizosphere environment, which would have made more nutrient availability in root zone consequently increased the nutrient absorption and translocation from source to sink Meena et al., (2017).

\section{Growth and yield attributes of wheat}

\section{Plant population}

The plant stand of wheat was recorded at harvest stage (table 4.0). The maximum plant stand at harvest were recorded with treatment

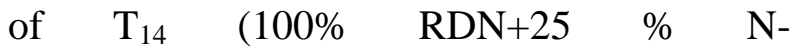
$\mathrm{VC}+\mathrm{S}+\mathrm{Zn}+\mathrm{Az}+\mathrm{PSB})$ and which was closely followed by $\mathrm{T}_{13} \quad(100 \%$ RDN $+25 \% \mathrm{~N}-$ $\mathrm{FYM}+\mathrm{S}+\mathrm{Zn}+\mathrm{Az}+\mathrm{PSB})$ but could not observe significant difference. The germination is affected due to vigor and genetic potentialities of seed, the seeds were common to all the treatments. This is due to better soil condition with application of organics and biofertilizers. This is in conformity with the results of Amruthesh et al., (2003) and Hameeda et al., (2008) who observed such increased germination due to biofertilizers application.

\section{Plant height}

The results of plant height clearly revealed that the application of different treatments in maize significantly influenced the plant height of wheat over control during both the years and on pooled mean basis (table 4.0). Among the $75 \%$ RDN combinations, the application

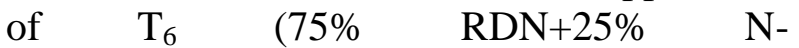
$\mathrm{VC}+\mathrm{S}+\mathrm{Zn}+\mathrm{Az}+\mathrm{PSB}$ ) recorded significantly taller plants over all the treatments of $75 \%$ RDN combinations however, remained at par

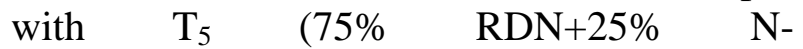
$\mathrm{FYM}+\mathrm{S}+\mathrm{Zn}+\mathrm{Az}+\mathrm{PSB})$.

The tallest plant was measured with $\mathrm{T}_{14}$ $(100 \% \mathrm{RDN}+25 \% \mathrm{~N}-\mathrm{VC}+\mathrm{S}+\mathrm{Zn}+\mathrm{Az}+\mathrm{PSB})$ followed by $\mathrm{T}_{13} \quad(100 \% \quad \mathrm{RDN}+25 \% \quad \mathrm{~N}-$ $\mathrm{FYM}+\mathrm{S}+\mathrm{Zn}+\mathrm{Az}+\mathrm{PSB}$ ) and significantly superior over rest of the treatments during 
both the years. It might be due to the positive impact of availability of individual plant nutrients and humic substances from manure and balanced supplement of nitrogen through inorganic fertilizers might have induced cell division, expansion of cell wall, meristematic activity, photosynthetic efficiency and regulation of water intake into the cells, resulting in the enhancement of yield parameters (Sekar, 2003). These findings are corroborated with the results of (Chandel et al., 2014 and Ram and Mir 2006).

\section{Spike length}

The data pertaining to spike length have been furnished in (table 5.0) revealed that the application of various treatments in maize significantly increased the spike length in wheat. The spike length varied from 7.23 to 10.28 and 7.26 to $10.36 \mathrm{~cm}$ during first and second years, respectively. The maximum number of spike length was measured in $\mathrm{T}_{14}$ $(100 \% \quad \mathrm{RDN}+25 \% \quad \mathrm{~N}-\mathrm{VC}+\mathrm{S}+\mathrm{Zn}+\mathrm{Az}+\mathrm{PSB})$ followed by $\mathrm{T}_{13} \quad(100 \% \quad \mathrm{RDN}+25 \% \quad \mathrm{~N}$ $\mathrm{FYM}+\mathrm{S}+\mathrm{Zn}+\mathrm{Az}+\mathrm{PSB}), \mathrm{T}_{6}(75 \% \mathrm{RDN}+25 \%$ $\mathrm{N}-\mathrm{VC}+\mathrm{S}+\mathrm{Zn}+\mathrm{Az}+\mathrm{PSB})$ and $\quad \mathrm{T}_{5} \quad(75 \%$ $\mathrm{RDN}+25 \% \mathrm{~N}-\mathrm{FYM}+\mathrm{S}+\mathrm{Zn}+\mathrm{Az}+\mathrm{PSB})$ and significantly superior to rest of the treatments. It clearly indicated that the addition of FYM or VC with S, Zn, Azotobacter and PSB had profound influence on spike length during both the years of experimentation. The similar findings were reported by (Chandel et al., 2014).

Table.1 Effect of different treatments on initial and final plant population of maize

\begin{tabular}{|c|c|c|c|c|}
\hline \multirow[t]{3}{*}{ Treatments combinations } & \multirow{2}{*}{\multicolumn{2}{|c|}{$\begin{array}{c}\text { Plant population per } \\
\text { running meter } \\
\text { Initial } \\
\end{array}$}} & \multirow{2}{*}{\multicolumn{2}{|c|}{$\begin{array}{c}\text { Plant population per } \\
\text { running meter } \\
\text { Final }\end{array}$}} \\
\hline & & & & \\
\hline & 2018-19 & 2019-20 & 2018-19 & 2019-20 \\
\hline$T_{1}$. Control & 6.11 & 6.13 & 5.98 & 5.95 \\
\hline $\mathrm{T}_{2 .} .75 \% \mathrm{RDN}$ & 6.20 & 6.22 & 6.07 & 6.10 \\
\hline $\mathrm{T}_{3 .} .75 \% \mathrm{RDN}+25 \% \mathrm{~N}-\mathrm{FYM}$ & 6.23 & 6.25 & 6.11 & 6.14 \\
\hline $\mathrm{T}_{4 .} .75 \% \mathrm{RDN}+25 \% \mathrm{~N}-\mathrm{VC}$ & 6.25 & 6.27 & 6.13 & 6.16 \\
\hline $\begin{array}{l}\mathrm{T}_{5 .} .75 \% \mathrm{RDN}+25 \% \mathrm{~N}- \\
\text { FYM+S+Zn+Az.+PSB }\end{array}$ & 6.43 & 6.46 & 6.32 & 6.35 \\
\hline $\mathrm{T}_{6 .} .75 \% \mathrm{RDN}+25 \% \mathrm{~N}-\mathrm{VC}+\mathrm{S}+\mathrm{Zn}+\mathrm{Az} .+\mathrm{PSB}$ & 6.45 & 6.48 & 6.43 & 6.47 \\
\hline $\mathrm{T}_{7 .} .100 \% \mathrm{RDN}$ & 6.28 & 6.30 & 6.16 & 6.19 \\
\hline$T_{8 .} 100 \% R D N+S$ & 6.32 & 6.35 & 6.18 & 6.21 \\
\hline $\mathrm{T}_{9 .} 100 \% \mathrm{RDN}+\mathrm{S}+\mathrm{Zn}$ & 6.41 & 6.44 & 6.33 & 6.37 \\
\hline \multirow{2}{*}{$\begin{array}{c}\mathrm{T}_{10 .} \mathbf{1 0 0 \%} \mathrm{RDN}+\mathrm{S}+\mathrm{Zn}+\mathrm{Az} .+\mathrm{PSB} \\
\mathrm{T}_{11 .} .100 \% \mathrm{RDN}+25 \% \mathrm{~N}-\mathrm{FYM}\end{array}$} & 6.48 & 6.51 & 6.37 & 6.41 \\
\hline & 6.37 & 6.40 & 6.28 & 6.31 \\
\hline $\mathrm{T}_{12 .} \mathbf{1 0 0} \% \mathrm{RDN}+25 \%-\mathrm{VC}$ & 6.40 & 6.43 & 6.30 & 6.33 \\
\hline $\begin{array}{l}\mathrm{T}_{13 .} 100 \% \mathrm{RDN}+25 \% \mathrm{~N}- \\
\text { FYM+S+Zn+Az.+PSB }\end{array}$ & 6.53 & 6.56 & 6.44 & 6.57 \\
\hline $\begin{array}{c}\mathrm{T}_{14.100 \% \mathrm{RDN}+25 \% \mathrm{~N}-} \\
\mathrm{VC}+\mathrm{S}+\mathrm{Zn}+\mathrm{Az} .+\mathrm{PSB}\end{array}$ & 6.55 & 6.58 & 6.47 & 6.59 \\
\hline SE(m) & 0.28 & 0.31 & 0.28 & 0.25 \\
\hline CD (5\%) & N.S. & N.S. & N.S. & N.S. \\
\hline
\end{tabular}


Table.2 Effect of different treatments on plant height and 1000 grain weight of maize

\begin{tabular}{|c|c|c|c|c|}
\hline \multirow[t]{2}{*}{ Treatments combinations } & \multicolumn{2}{|c|}{ Plant height (cm) } & \multicolumn{2}{|c|}{1000 grain weight $(g)$} \\
\hline & 2018-19 & 2019-20 & 2018-19 & 2019-20 \\
\hline$T_{1}$. Control & 175.63 & 175.61 & 221.81 & 221.80 \\
\hline $\mathrm{T}_{2} .75 \% \mathrm{RDN}$ & 177.85 & 177.88 & 222.15 & 222.18 \\
\hline $\mathrm{T}_{3 .} .75 \% \mathrm{RDN}+25 \% \mathrm{~N}-\mathrm{FYM}$ & 178.23 & 178.26 & 223.21 & 223.24 \\
\hline $\mathrm{T}_{4} .75 \% \mathrm{RDN}+25 \% \mathrm{~N}-\mathrm{VC}$ & 178.32 & 178.35 & 223.25 & 223.30 \\
\hline $\mathrm{T}_{5 .} .75 \% \mathrm{RDN}+25 \% \mathrm{~N}-\mathrm{FYM}+\mathrm{S}+\mathrm{Zn}+\mathrm{Az} .+\mathrm{PSB}$ & 179.05 & 179.09 & 223.71 & 223.75 \\
\hline $\mathrm{T}_{6 .} .75 \% \mathrm{RDN}+25 \% \mathrm{~N}-\mathrm{VC}+\mathrm{S}+\mathrm{Zn}+\mathrm{Az} .+\mathrm{PSB}$ & 179.13 & 179.17 & 223.80 & 223.84 \\
\hline $\mathrm{T}_{7.100 \% \mathrm{RDN}}$ & 178.42 & 178.45 & 223.33 & 223.36 \\
\hline$T_{8} .100 \% R D N+S$ & 178.51 & 178.54 & 223.40 & 223.43 \\
\hline $\mathrm{T}_{9 .} \mathbf{1 0 0 \%} \mathrm{RDN}+\mathrm{S}+\mathrm{Zn}$ & 178.8 & 178.83 & 223.62 & 223.66 \\
\hline$T_{10 .} \cdot 100 \% R D N+S+Z n+A z .+P S B$ & 179.2 & 179.24 & 223.85 & 223.90 \\
\hline $\mathrm{T}_{11 .} \mathbf{1 0 0 \%} \mathrm{RDN}+25 \% \mathrm{~N}-\mathrm{FYM}$ & 178.66 & 178.69 & 223.48 & 223.51 \\
\hline $\mathrm{T}_{12 .} \mathbf{1 0 0 \%} \mathrm{RDN}+25 \%-\mathrm{VC}$ & 178.75 & 178.78 & 223.55 & 223.58 \\
\hline $\mathrm{T}_{13 .} .100 \% \mathrm{RDN}+25 \% \mathrm{~N}-\mathrm{FYM}+\mathrm{S}+\mathrm{Zn}+\mathrm{Az} .+\mathrm{PSB}$ & 179.28 & 179.32 & 223.93 & 223.97 \\
\hline $\mathrm{T}_{14 .} .100 \% \mathrm{RDN}+25 \% \mathrm{~N}-\mathrm{VC}+\mathrm{S}+\mathrm{Zn}+\mathrm{Az} .+\mathrm{PSB}$ & 179.33 & 179.37 & 224.06 & 224.10 \\
\hline $\mathbf{S E}(\mathbf{m})$ & 0.45 & 0.62 & 0.39 & 0.41 \\
\hline CD (5\%) & 1.30 & 1.81 & 1.15 & 1.18 \\
\hline
\end{tabular}

Table.3 Effect of different treatments combinations on diameter and length of cobs

\begin{tabular}{|c|c|c|c|c|}
\hline \multirow[t]{2}{*}{ Treatments combinations } & \multicolumn{2}{|c|}{ Cob diameter $(\mathrm{cm})$} & \multicolumn{2}{|c|}{ Cob length (cm) } \\
\hline & 2018-19 & 2019-20 & 2018-19 & 2019-20 \\
\hline $\mathbf{T}_{1} \cdot$ Control & 7.71 & 7.69 & 12.33 & 12.32 \\
\hline $\mathrm{T}_{2 .} .75 \% \mathrm{RDN}$ & 8.25 & 8.28 & 13.58 & 13.60 \\
\hline $\mathrm{T}_{3 .} .75 \% \mathrm{RDN}+25 \% \mathrm{~N}-\mathrm{FYM}$ & 8.32 & 8.36 & 13.76 & 13.78 \\
\hline $\mathrm{T}_{4} .75 \% \mathrm{RDN}+25 \% \mathrm{~N}-\mathrm{VC}$ & 8.36 & 8.40 & 13.80 & 13.82 \\
\hline $\mathrm{T}_{5 .} \mathbf{7 5} \% \mathrm{RDN}+25 \% \mathrm{~N}-\mathrm{FYM}+\mathrm{S}+\mathrm{Zn}+\mathrm{Az} .+\mathrm{PSB}$ & 8.53 & 8.57 & 14.20 & 14.22 \\
\hline $\mathrm{T}_{6 .} .75 \% \mathrm{RDN}+25 \% \mathrm{~N}-\mathrm{VC}+\mathrm{S}+\mathrm{Zn}+\mathrm{Az} .+\mathrm{PSB}$ & 8.56 & 8.60 & 14.28 & 14.30 \\
\hline $\mathrm{T}_{7.100 \% \mathrm{RDN}}$ & 8.39 & 8.42 & 13.83 & 13.85 \\
\hline $\mathrm{T}_{8 .} \mathbf{1 0 0 \%} \mathrm{RDN}+\mathrm{S}$ & 8.41 & 8.44 & 13.95 & 13.97 \\
\hline$T_{9 .} 100 \%$ RDN+S+Zn & 8.50 & 8.53 & 14.13 & 14.15 \\
\hline $\mathrm{T}_{10 .} 100 \% \mathrm{RDN}+\mathrm{S}+\mathrm{Zn}+\mathrm{Az} .+\mathrm{PSB}$ & 8.61 & 8.65 & 14.36 & 14.34 \\
\hline $\mathrm{T}_{11} .100 \% \mathrm{RDN}+25 \% \mathrm{~N}-\mathrm{FYM}$ & 8.43 & 8.46 & 14.03 & 14.02 \\
\hline $\mathrm{T}_{12 .} .100 \% \mathrm{RDN}+25 \%-\mathrm{VC}$ & 8.46 & 8.49 & 14.10 & 14.09 \\
\hline $\begin{array}{c}\text { T }_{13 .} 100 \% \mathrm{RDN}+25 \% \mathrm{~N}- \\
\text { FYM+S+Zn+Az.+PSB }\end{array}$ & 8.61 & 8.65 & 14.47 & 14.45 \\
\hline $\mathrm{T}_{14 .} 100 \% \mathrm{RDN}+25 \% \mathrm{~N}-\mathrm{VC}+\mathrm{S}+\mathrm{Zn}+\mathrm{Az} .+\mathrm{PSB}$ & 8.65 & 8.70 & 14.56 & 14.54 \\
\hline SE(m) & 0.061 & 0.089 & 0.19 & 0.13 \\
\hline CD $(5 \%)$ & 0.177 & 0.258 & 0.55 & 0.36 \\
\hline
\end{tabular}


Table.4 Effect of previously applied treatments on plant population and plant height

\begin{tabular}{|c|c|c|c|c|}
\hline \multirow[t]{2}{*}{ Treatments combinations } & \multicolumn{2}{|c|}{$\begin{array}{l}\text { Plant population per } \\
\text { running meter }\end{array}$} & \multicolumn{2}{|c|}{ Plant height (cm) } \\
\hline & 2018-19 & 2019-20 & 2018-19 & 2019-20 \\
\hline$T_{1}$. Control & 28.55 & 28.67 & 82.76 & 82.78 \\
\hline $\mathrm{T}_{2 .} .75 \% \mathrm{RDN}$ & 29.32 & 29.48 & 83.62 & 83.65 \\
\hline $\mathrm{T}_{3} .75 \% \mathrm{RDN}+25 \% \mathrm{~N}-\mathrm{FYM}$ & 29.53 & 29.79 & 84.68 & 84.70 \\
\hline $\mathrm{T}_{4} .75 \% \mathrm{RDN}+25 \% \mathrm{~N}-\mathrm{VC}$ & 29.58 & 29.86 & 84.70 & 84.73 \\
\hline $\mathrm{T}_{5} .75 \% \mathrm{RDN}+25 \% \mathrm{~N}-\mathrm{FYM}+\mathrm{S}+\mathrm{Zn}+\mathrm{Az} .+\mathrm{PSB}$ & 29.96 & 30.35 & 85.00 & 85.04 \\
\hline $\mathrm{T}_{6 .} .75 \% \mathrm{RDN}+25 \% \mathrm{~N}-\mathrm{VC}+\mathrm{S}+\mathrm{Zn}+\mathrm{Az} .+\mathrm{PSB}$ & 30.02 & 30.50 & 85.03 & 85.07 \\
\hline $\mathrm{T}_{7 .} 100 \%$ RDN & 29.4 & 29.58 & 84.66 & 84.69 \\
\hline $\mathrm{T}_{8} \cdot 100 \% \mathrm{RDN}+\mathrm{S}$ & 29.61 & 29.91 & 84.75 & 84.78 \\
\hline$T_{9 .} 100 \% \mathrm{RDN}+\mathrm{S}+\mathrm{Zn}$ & 29.67 & 29.99 & 84.77 & 84.80 \\
\hline$T_{10} .100 \% R D N+S+Z n+A z .+P S B$ & 29.89 & 30.29 & 84.96 & 85.00 \\
\hline $\mathrm{T}_{11 .} 100 \% \mathrm{RDN}+25 \% \mathrm{~N}-\mathrm{FYM}$ & 29.76 & 30.12 & 84.79 & 84.83 \\
\hline $\mathrm{T}_{12 .} .100 \% \mathrm{RDN}+25 \%-\mathrm{VC}$ & 29.8 & 30.20 & 84.81 & 84.85 \\
\hline $\mathrm{T}_{13 .} .100 \% \mathrm{RDN}+25 \% \mathrm{~N}-\mathrm{FYM}+\mathrm{S}+\mathrm{Zn}+\mathrm{Az} .+\mathrm{PSB}$ & 30.11 & 30.59 & 85.08 & 85.12 \\
\hline $\mathrm{T}_{14 .} 100 \% \mathrm{RDN}+25 \% \mathrm{~N}-\mathrm{VC}+\mathrm{S}+\mathrm{Zn}+\mathrm{Az} .+\mathrm{PSB}$ & 30.17 & 30.71 & 85.11 & 85.15 \\
\hline $\mathbf{S E}(\mathbf{m})$ & 0.78 & 0.89 & 0.080 & 0.97 \\
\hline CD $(5 \%)$ & N.S. & N.S. & 0.23 & 0.28 \\
\hline
\end{tabular}

Table.5 Effect of previously applied treatments on length of spike and test weight

\begin{tabular}{|c|c|c|c|c|}
\hline \multirow[t]{2}{*}{ Treatments combinations } & \multicolumn{2}{|c|}{ Spike length (cm) } & \multicolumn{2}{|c|}{ Test weight (g) } \\
\hline & 2018-19 & 2019-20 & 2018-19 & 2019-20 \\
\hline $\mathbf{T}_{1} \cdot$ Control & 7.23 & 7.26 & 39.08 & 39.11 \\
\hline $\mathrm{T}_{2 .} .75 \% \mathrm{RDN}$ & 8.56 & 8.61 & 39.21 & 39.25 \\
\hline $\mathrm{T}_{3 .} .75 \% \mathrm{RDN}+25 \% \mathrm{~N}-\mathrm{FYM}$ & 9.12 & 9.19 & 39.50 & 39.54 \\
\hline $\mathrm{T}_{4} .75 \% \mathrm{RDN}+25 \% \mathrm{~N}-\mathrm{VC}$ & 9.16 & 9.23 & 39.52 & 39.56 \\
\hline $\mathrm{T}_{5 .} \mathbf{7 5} \% \mathrm{RDN}+25 \% \mathrm{~N}-\mathrm{FYM}+\mathrm{S}+\mathrm{Zn}+\mathrm{Az} .+\mathrm{PSB}$ & 9.88 & 9.96 & 40.28 & 40.32 \\
\hline $\mathrm{T}_{6 .} .75 \% \mathrm{RDN}+25 \% \mathrm{~N}-\mathrm{VC}+\mathrm{S}+\mathrm{Zn}+\mathrm{Az} .+\mathrm{PSB}$ & 9.91 & 10.02 & 40.30 & 40.37 \\
\hline $\mathrm{T}_{7.100 \% \mathrm{RDN}}$ & 8.91 & 8.96 & 39.37 & 39.40 \\
\hline $\mathrm{T}_{8 .} \mathbf{1 0 0 \%} \mathrm{RDN}+\mathrm{S}$ & 9.20 & 9.26 & 39.63 & 39.66 \\
\hline$T_{9 .} 100 \%$ RDN+S+Zn & 9.33 & 9.39 & 39.68 & 39.71 \\
\hline $\mathrm{T}_{10 .} 100 \% \mathrm{RDN}+\mathrm{S}+\mathrm{Zn}+\mathrm{Az} .+\mathrm{PSB}$ & 9.76 & 9.82 & 40.15 & 40.19 \\
\hline $\mathrm{T}_{11} .100 \% \mathrm{RDN}+25 \% \mathrm{~N}-\mathrm{FYM}$ & 9.62 & 9.69 & 39.71 & 39.75 \\
\hline $\mathrm{T}_{12 .} 100 \% \mathrm{RDN}+25 \%-\mathrm{VC}$ & 9.66 & 9.73 & 39.73 & 39.77 \\
\hline $\begin{array}{c}\text { T }_{13 .} 100 \% \mathrm{RDN}+25 \% \mathrm{~N}- \\
\text { FYM+S+Zn+Az.+PSB }\end{array}$ & 10.23 & 10.31 & 40.52 & 40.56 \\
\hline $\mathrm{T}_{14 .} 100 \% \mathrm{RDN}+25 \% \mathrm{~N}-\mathrm{VC}+\mathrm{S}+\mathrm{Zn}+\mathrm{Az} .+\mathrm{PSB}$ & 10.28 & 10.36 & 40.53 & 40.57 \\
\hline SE(m) & 0.133 & 0.138 & 0.255 & 0.257 \\
\hline CD $(5 \%)$ & 0.39 & 0.41 & NS & NS \\
\hline
\end{tabular}




\section{Test weight}

The data pertaining to 1000 grain weight as presented in table (table 5.0) revealed that the application of various treatments in maize. The test weight of grain of wheat varied from 39.08 to 40.53 and 39.11 to $40.57 \mathrm{~g}$ during first and second years, respectively. The test weight of wheat could not make significant difference due to applied treatments in maize crop. It is evident from table that the application of FYM or VC had pronounced impact on test weight compare to only RDN of 75 or $100 \%$. Though, maximum test weight was recorded with $\mathrm{T}_{14}(100 \% \mathrm{RDN}+25 \% \mathrm{~N}-$ $\mathrm{VC}+\mathrm{S}+\mathrm{Zn}+\mathrm{Az}+\mathrm{PSB})$ followed by $\mathrm{T}_{13}(100 \%$ $\mathrm{RDN}+25 \% \quad \mathrm{~N}-\mathrm{FYM}+\mathrm{S}+\mathrm{Zn}+\mathrm{Az}+\mathrm{PSB}), \quad \mathrm{T}_{6}$ $(75 \% \mathrm{RDN}+25 \% \mathrm{~N}-\mathrm{VC}+\mathrm{S}+\mathrm{Zn}+\mathrm{Az}+\mathrm{PSB})$ and $\mathrm{T}_{5} \quad(75 \% \quad \mathrm{RDN}+25 \% \quad \mathrm{~N}-$ $\mathrm{FYM}+\mathrm{S}+\mathrm{Zn}+\mathrm{Az}+\mathrm{PSB})$ during both the years. This might be due to relatively more nutrient supply in available form which enhanced the plant growth and development ultimately increase in test weight. The results are corroborated with the findings of Rasool et al., (2007) and Chandel et al., (2014).

The maximum value regarding growth and yield attributes of maize and wheat were recorded with the treatment of $\mathrm{T}_{14}(100 \%$ $\mathrm{RDN}+25 \% \quad \mathrm{~N}-\mathrm{VC}+\mathrm{S}+\mathrm{Zn}+\mathrm{Az}+\mathrm{PSB})$ which was statistically at par with $\mathrm{T}_{13}$ where FYM was given in place of VC. It was significantly superior for all the growth parameters except plant population than control during both the years of experimentation. It might be concluded that the integration of organic and inorganic sources along bio-inoculants proved better over sole inorganic or organic sources in terms of cost optimization as well as growth parameters.

\section{References}

Amruthesh, K. N., Raj, S. N., Kiran, B., Shetty, H. S. and Reddy, M. S. 2003.
Growth promotion by plant growth promoting rhizobacteria in some economically important crop plants. In: Sixth International PGPR Workshop, 510 October, Calicut, India, 97- 103.

Anonymous, 2018. Agricultural Statistics at a Glance. Government of India Ministry of Agriculture \& Farmers Welfare Department of Agriculture, Cooperation \& Farmers Welfare Directorate of Economics and Statistics.

Bhattacharyya, R., S. Kundu, V. Prakash and H. S. Gupta. 2008. "Sustainability under combined application of mineral and organic fertilizers in a rain-fed soybeanwheat system of Indian Himalayas." European Journal of Agronomy, 28: 3346.

Balasubramanian, A. and Ramamoorthy, K., 1996. Effect of nitrogen and phosphorus fertilization on juice yield and quality of sweet sorghum (Sorghum bicolor L.). Madras Agricultural Journal, 83(7): 463-464.

Brar, B. S., Singh, J., Singh, G., and Kumar, G. (2015). Effects of long term application of inorganic and organic fertilizers on soil organic carbon and physical properties in Maize-Wheat rotation. Agron., (5): 220-238.

Chandel, B. S., Singh, H. and Singh, B. 2014. Direct and residual effect of nutrient management in wheat-maize cropping sequence. Journal of Indian Society of Soil Science, 61(2):126-130.

Gaur, A. C. 1994. "Bulk organic manures and crop residual." In: H. L. S. Tandon, J. Ced. (Eds.) Fertilizers, Organic manures, Recyclable Wastes and Biofertilizers, 3651. Fertilizer Development and Consultation Organization. New Delhi, India.

Gunri, S. K. and Nath, R. (2012). Effect of organic manures, biofertlizers and biopesticides on productivity of summer Groundnut in red and laterite zone. 
HLPE. 2013. Investing in smallholder agriculture for food security. A report by the high level panel of experts on food security and nutrition of the committee on world food security, Rome.

Kannan, R. L., Dhivya, M., Abinaya, D., Lekshmi, K. R. and Krishna, K. S. 2013. "Effect of integrated nutrient management on soil fertility and productivity in maize," Bull. Env. Pharmacol. Life Sci., 2: 61-67.

Hameeda, B., Harini, G., Rupela, O. P., Wani S. P. and Gopala Reddy, 2008. Growth promotion of maize by phosphate solubilizing bacteria isolated from composts and macrofauna. Microbiological Research, 163: 234-242. Naveed, M., Khalid, M., Jones, D. L., Ahmad, R. and Zahir, Z. A. 2008. Relative efficacy of Pseudomonas spp., containing ACC deaminase for improving growth and yield of maize (Zea mays L.) in the presence of organic fertilizer. Pak. J. Bot., 40(3): 1243-1251.

Prasad, B. and M. K. Sinha. 2000. Effects of fertilizers and organic manures on crop yield, nutrient balance and soil properties in rice-wheat cropping system in Bihar Rice-Wheat consortium New Dehli, India. pp. 105-109.

Prasad, B. and M. K. Sinha. 2000. Effects of fertilizers and organic manures on crop yield, nutrient balance and soil properties in rice-wheat cropping system in Bihar Rice-Wheat consortium New Dehli, India. pp. 105-109.

Rasool, R., Kukal, S. S. and Hira, G. S. 2007.
Soil physical fertility and crop performance as affected by long-term application of FYM and inorganic fertilizers in rice-wheat system. Soil and Tillage Research96: 64-72.

Sarwar, M., Jilani, G., Rafique, E., Akhtar, M. E. and Chaudhry, A. N. 2012. Impact of integrated nutrient management on yield and nutrient uptake by maize under rainfed conditions. Pakistan Journal of Nutrition 11 (1): 27-33.

Swarup, A., and Wanjani, R. H. 2002. Three decades of all India coordinated research project on long - term fertilizer experiments to study changes in soil quality, crop productivity and sustainability. Indian Institute of Soil Science, Bhopal, India, pp-59.

Sekar, A. 2003. Studies on the evaluation of sugarcane variety and production technologies for sugarcane productivity in coastal region of Tamil Nadu. Ph.D. thesis, Annamalai University, Annamalainagar, Tamil Nadu.

Tulsa Ram and Mir, M. S. (2006). Effect of integrated nutrient management on yield and yield-attributing characters of wheat (Triticum aestivum). Indian Journal of Agronomy 51(3): 189-192.

Yogendra Kumar., Rani Saxena, K. C., Gupta and Fageria, V. D., 2013. Yield and Yield attributes of Groundnut as influenced by organic practices in semi arid region. International journal of Agriculture Environment \& Bitechnology (IJAEB), 6(4): 605-610.

\section{How to cite this article:}

Pushpendra Kumar, S. D. Dubey, U. S. Tiwari, R. K. Pandey, Karam Hussain and Singh, R. K. 2021. Effect of VC, FYM, S, Zn, Azotobacter and PSB on Growth and Yield Attributes of Maize and Wheat. Int.J.Curr.Microbiol.App.Sci. 10(06): 764-773. doi: https://doi.org/10.20546/ijcmas.2021.1006.083 